\title{
Gross Alpha and Beta Decision Levels for the Environmental Air Monitoring Program for the Idaho National Laboratory
}

\author{
June 2017
}

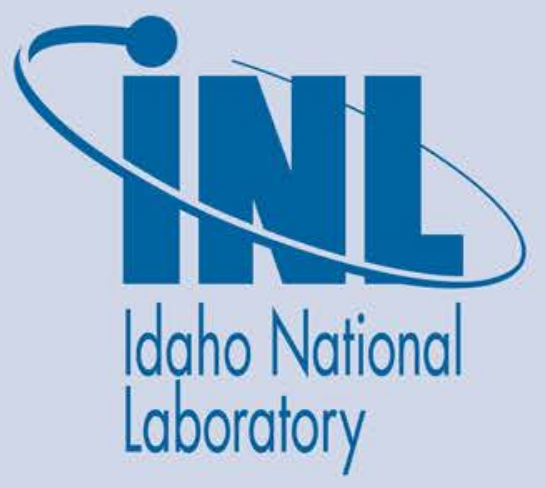

The INL is a U.S. Department of Energy National Laboratory operated by Battelle Energy Alliance 


\section{DISCLAIMER}

This information was prepared as an account of work sponsored by an agency of the U.S. Government. Neither the U.S. Government nor any agency thereof, nor any of their employees, makes any warranty, expressed or implied, or assumes any legal liability or responsibility for the accuracy, completeness, or usefulness, of any information, apparatus, product, or process disclosed, or represents that its use would not infringe privately owned rights. References herein to any specific commercial product, process, or service by trade name, trade mark, manufacturer, or otherwise, does not necessarily constitute or imply its endorsement, recommendation, or favoring by the U.S. Government or any agency thereof. The views and opinions of authors expressed herein do not necessarily state or reflect those of the U.S. Government or any agency thereof. 
INL/EXT-17-42255

Revision 0

\section{Gross Alpha and Beta Decision Levels for the Environmental Air Monitoring Program for the Idaho National Laboratory}

June 2017

Idaho National Laboratory Idaho Falls, Idaho 83415

http://www.inl.gov

Prepared for the

U.S. Department of Energy

Office of Nuclear Energy

Under DOE Idaho Operations Office

Contract DE-AC07-05ID14517 



\begin{abstract}
This report provides a comprehensive analysis of alpha and beta radiation data collected from air monitoring sites at or near Idaho National Laboratory from April 2006 through February 2017. These data were used to compute monitoring limits that will be used to assess future alpha and beta radiation measurements. Data were analyzed for seasonality, stationarity, and other data issues that may impact the calculation and use of the monitoring limits.
\end{abstract}




\section{CONTENTS}

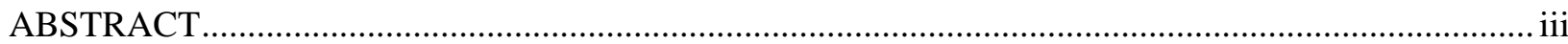

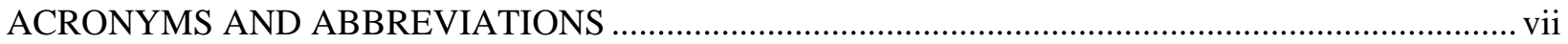

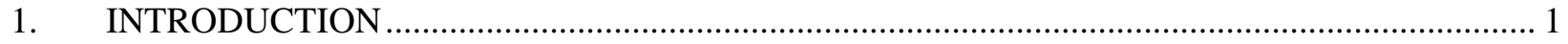

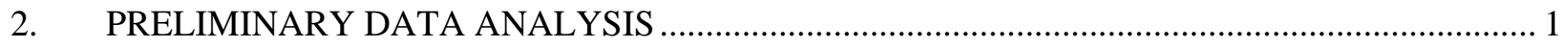

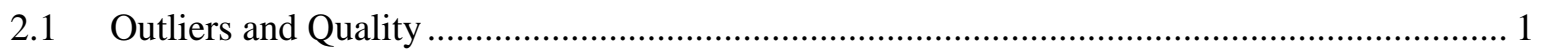

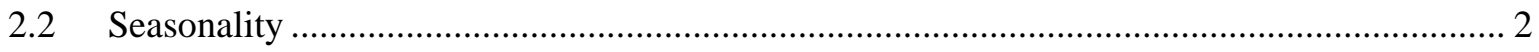

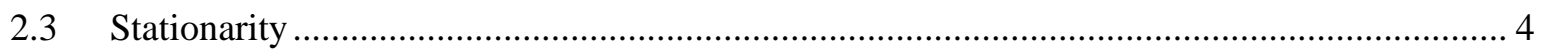

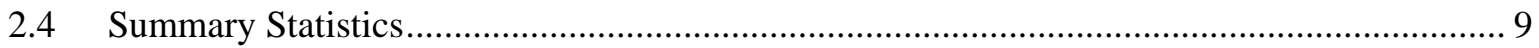

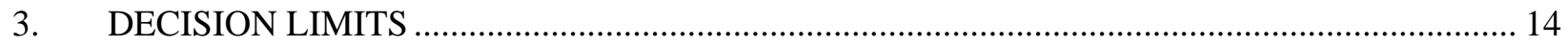

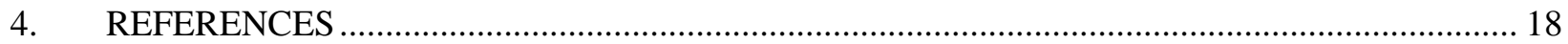

\section{FIGURES}

Figure 1. Alpha and beta concentrations measured at INL air monitoring locations, 2006-2017. The gross alpha and gross beta data each have one extreme outlier........................................ 2

Figure 2. Gross alpha concentrations by month. The average concentration for each month, the 2 standard deviation and 5 standard deviation limits, and the previous air monitoring limit are included for reference.

Figure 3. Gross beta concentrations by month. The average concentration for each month, the 2 standard deviation and 5 standard deviation limits, and the previous air monitoring limit are included for reference.

Figure 4. Residual plots, histograms, and normal-quantile plots of residuals from the ANOVA model generated using the raw alpha data and the natural logarithm of the alpha data.

Figure 5. Residual plots, histograms, and normal-quantile plots of residuals from the ANOVA model generated using the raw beta data and the natural logarithm of the beta data.

Figure 6. Boxplot showing the concentrations of alpha radiation in each monitor location......................... 7

Figure 7. Boxplot showing the concentrations of beta radiation in each monitor location........................... 8

Figure 8. Histograms, normal-quantile plots, and boxplots for gross alpha and gross beta

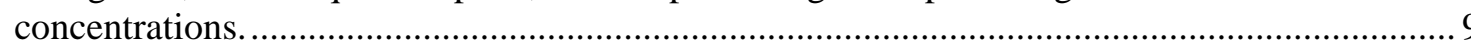

Figure 9. Gross alpha concentration by month. New decision limits are included for context. ................. 15

Figure 10. Gross beta concentration by month. New decision limits are included for context. ................. 15

Figure 11. Alpha concentrations observed by location. The line on the graph is the decision limit, which is included for context

Figure 12. Beta concentrations observed by location. The line on the graph is the decision limit, which is included for context. 


\section{TABLES}

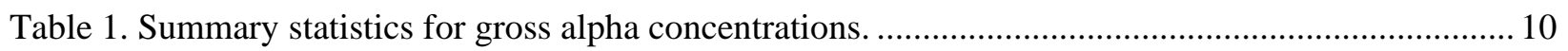

Table 2. Five-number summary for gross alpha concentrations.......................................................... 11

Table 3. Summary statistics for gross beta concentrations. ................................................................. 12

Table 4. Five-number summary for gross beta concentrations.............................................................. 13

Table 5. Decision limits for gross alpha and gross beta air monitoring............................................... 14 


\section{ACRONYMS AND ABBREVIATIONS}

$\begin{array}{ll}\text { ANLW } & \text { Argonne National Laboratory - West } \\ \text { ANOVA } & \text { analysis of variance } \\ \text { ARA } & \text { Auxiliary Reactor Area } \\ \text { BLKFT } & \text { Blackfoot } \\ \text { CFA } & \text { Central Facilities Area } \\ \text { CPP } & \text { Chemical Processing Plant } \\ \text { CRATERS } & \text { Craters of the Moon National Monument \& Preserve } \\ \text { EBR 1 } & \text { Experimental Breeder Reactor I } \\ \text { EFS } & \text { Experimental Field Station } \\ \text { EPA } & \text { Environmental Protection Agency } \\ \text { IF } & \text { Idaho Falls } \\ \text { INL } & \text { Idaho National Laboratory } \\ \text { INTEC } & \text { Idaho Nuclear Technology and Engineering Center } \\ \text { IRC } & \text { INL Research Center } \\ \text { LOC } & \text { location } \\ \text { MFC } & \text { Materials and Fuels Complex } \\ \text { NRF } & \text { Naval Reactors Facility } \\ \text { PBF } & \text { Power Burst Facility } \\ \text { RTC } & \text { Reactor Technology Complex } \\ \text { RWMC } & \text { Radioactive Waste Management Complex } \\ \text { SMC } & \text { Specific Manufacturing Capability } \\ \text { TAN } & \text { Test Area North } \\ \text { TRA } & \text { Test Reactor Area } \\ \text { UTL } & \text { upper tolerance limit } \\ & \end{array}$




\section{Gross Alpha and Beta Decision Levels for the Environmental Air Monitoring Program for the Idaho National Laboratory}

\section{INTRODUCTION}

Data are collected from air monitors in and around Idaho National Laboratory (INL) weekly. This report provides a statistical analysis of the gross alpha and gross beta measurements collected from these sampling events. Historical data are used to compute decision limits that are presented at the end of this report. A preliminary data analysis is also included to ensure that the appropriate decision limits were calculated and that information is available to aid in the use of the decision limits.

The R statistical package was used to create the graphs and perform all calculations except where otherwise noted (R Core Team 2016). Data manipulation was done using base $\mathrm{R}$ and the dplyr package (Wickam and Francois 2015). Graphs were constructed using base R and ggplot2 (Wickam 2009). ProUCL was used to compute the decision limits (EPA 2016).

\section{PRELIMINARY DATA ANALYSIS}

Air monitoring data were obtained from April 2006 through February 2017. The data were examined for undesirable traits such as outliers and inconsistencies that indicate possible data quality issues. Alpha and beta radiation data were assessed for seasonality, stationarity, and normality. Each of these traits is discussed in this section. Detection limits are used in place of nondetects for graphs. Kaplan-Meier estimation was used for computations to appropriately address nondetects.

\subsection{Outliers and Quality}

The data show that there was one extreme outlier in the alpha data and one in the beta data. They did not occur on the same dates or in the same years. The outlier for the alpha data occurred on September 6, 2006, and the outlier for the beta data occurred on February 24, 2010. Because there was so much data over the years involved, these two points can be removed from the dataset without altering the integrity of the dataset. Their removal improves the quality of the analysis. Figure 1 shows the two outliers relative to the rest of the data.

Data were also examined for anomalies that indicate dubious data quality. Some of the data collected in 2006 and 2007 had detection limits that were reported as 0. Several of the observations in 2006 and 2007 had reported concentrations that were less than the detection limit and were not U-flagged. Some of these values had reported concentrations that were negative and were not flagged as nondetects. Because of these issues, only data collected during 2008 and later were used to create the decision limits. 

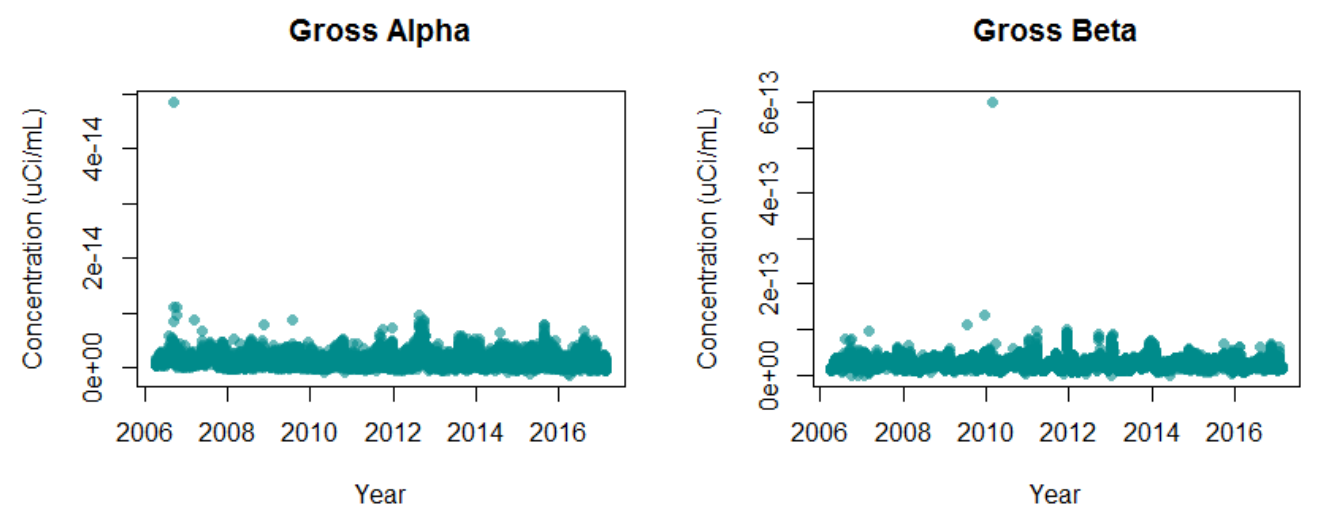

Figure 1. Alpha and beta concentrations measured at INL air monitoring locations, 2006-2017. The gross alpha and gross beta data each have one extreme outlier.

\subsection{Seasonality}

Data were assessed for seasonality, which is a cyclic pattern that occurs over time (EPA 2009 and Gilbert 1987). Figures 2 and 3 show the average alpha and beta radiation by month. It is clear that the concentrations differ from month to month. This means that there is seasonality in the data. Figure 2 shows that the concentrations of gross alpha peak in August and are lowest in March. Concentrations are more variable from July through September than other times of the year. There is less variability in concentrations for measurements collected from March through May than the rest of the year. Figure 3 shows that the concentrations of gross beta peak in December and January and are lowest during the summer. Variability is low during the summer months but is high from December to March. It was decided that, even though there is clear seasonality in the data, only one monitoring limit would be calculated for each analyte monitored. These graphs provide context for interpreting air monitoring readings obtained with respect to the time of year that the readings are taken. For example, if the air monitoring limit for gross alpha is exceeded in August it is known that the concentration may still be within the normal range. However, if the alpha limit is exceeded in March, closer examination will be required. 


\section{Gross Alpha}

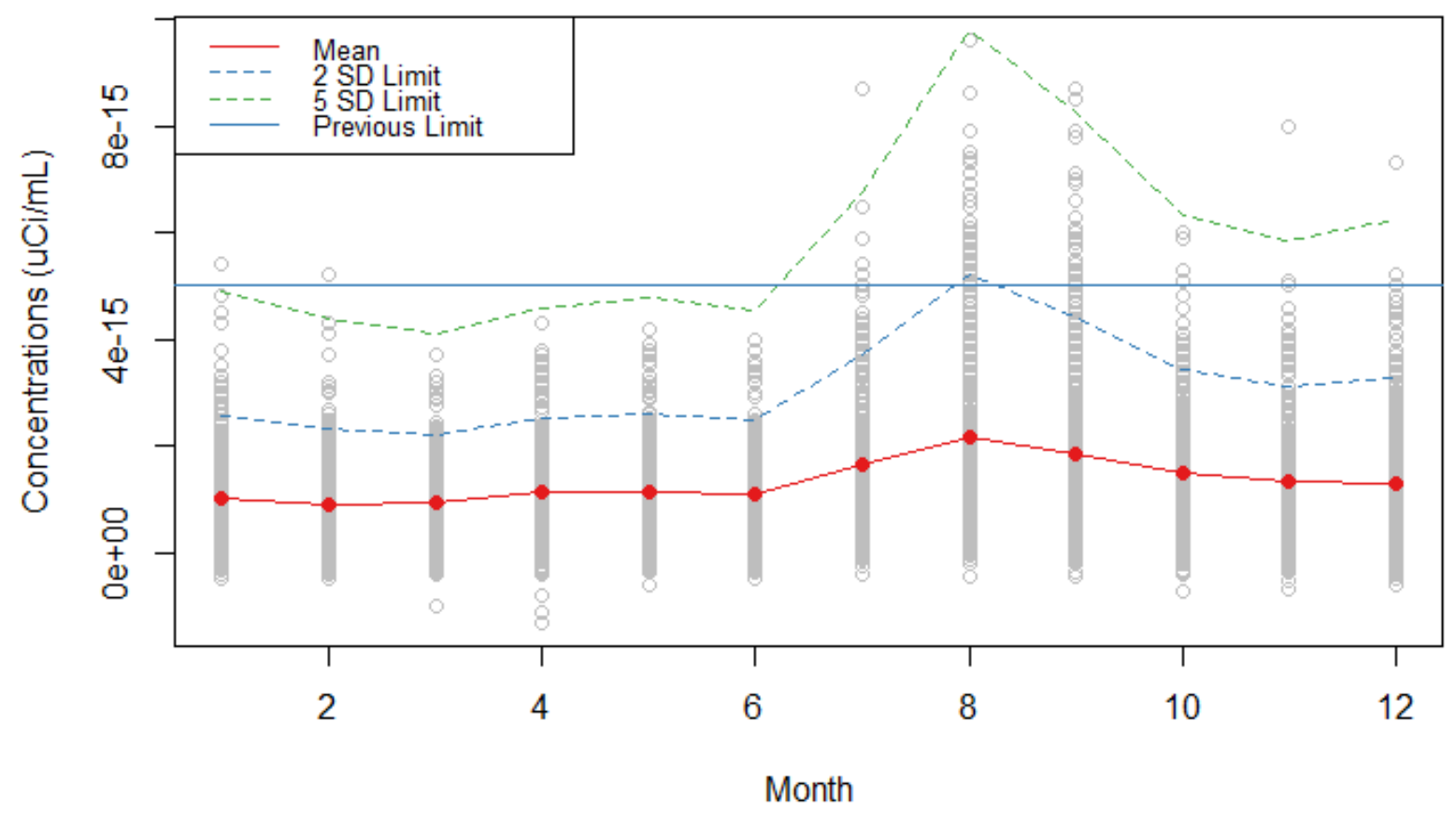

Figure 2. Gross alpha concentrations by month. The average concentration for each month, the 2 standard deviation and 5 standard deviation limits, and the previous air monitoring limit are included for reference.

Gross Beta

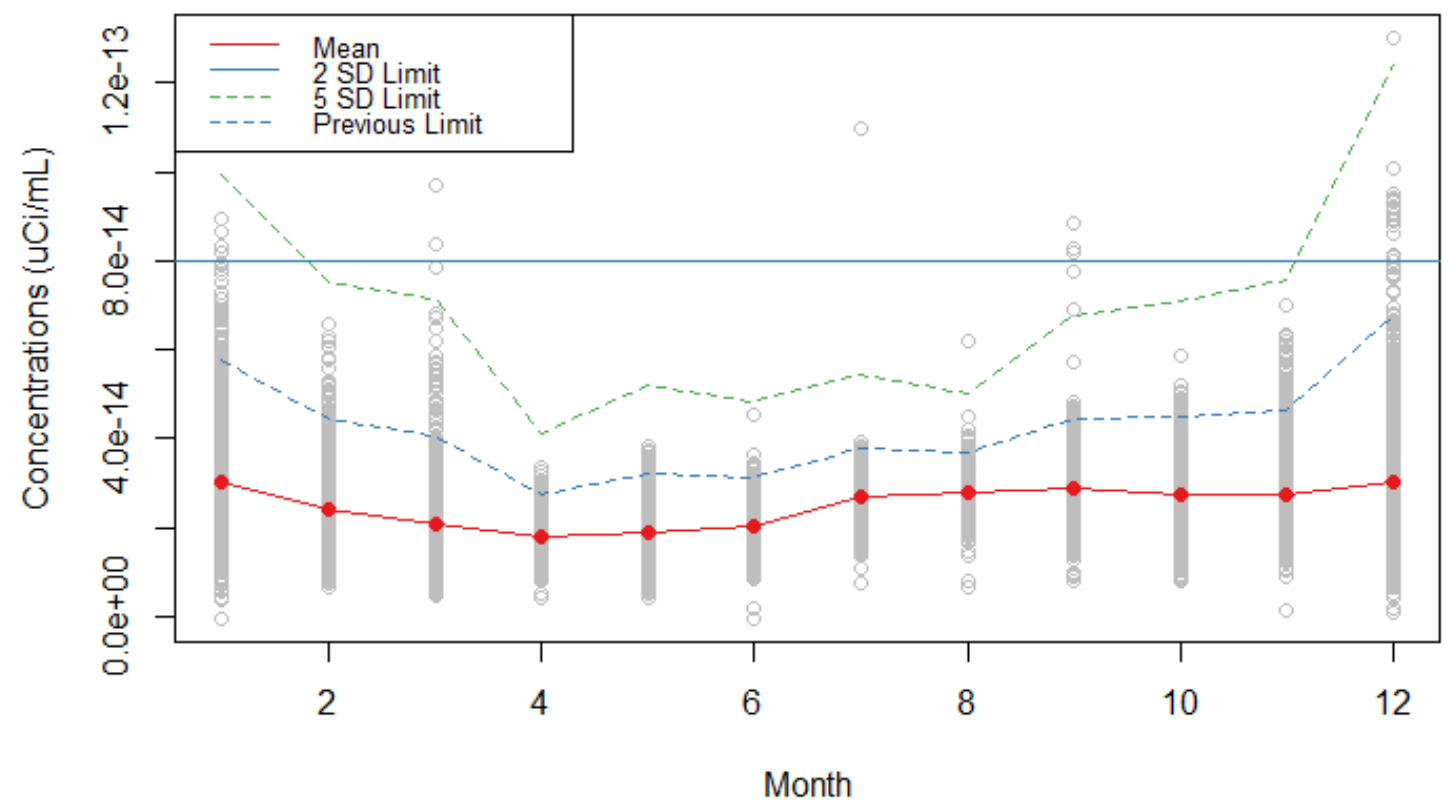

Figure 3. Gross beta concentrations by month. The average concentration for each month, the 2 standard deviation and 5 standard deviation limits, and the previous air monitoring limit are included for reference. 


\subsection{Stationarity}

Data were also examined for stationarity. Stationarity is when the mean concentration and standard deviation are the same across the area being monitored (EPA 2009 and Gilbert 1987). Analysis of variance (ANOVA) and Kruskal-Wallis were used to determine if the mean or median concentration was different at the different air monitoring sites. ANOVA and Kruskal-Wallis can indicate only if at least one site is different from the others—but cannot identify which sites are different from each other.

The alpha and beta data were examined for normality prior to examination of the ANOVA results. ANOVA assumes that the residuals of the model are normally distributed. Figure 4 shows the distribution of the residuals obtained from the ANOVA model computed using the raw alpha data and the distribution of the residuals from the model constructed from the natural logarithm of the alpha data. Figure 5 shows the same for the beta data. The first plot in the figure is a residual plot. The points on this plot should look like a random cloud. The second plot is a histogram. It shows the shape, or distribution, of the residuals. If the residuals follow a normal distribution then the histogram will have a bell shape. The histogram can also show if the data are symmetric even when they are not normally distributed. Symmetry can compensate for some degree of non-normality. The third plot is a normal-quantile plot. This is one of the most effective ways to determine if the residuals come from a normal distribution. If the residuals are normally distributed then this plot will follow a straight line. Figure 4 shows that the residuals from the raw and transformed gross alpha data are not normally distributed. The residuals from the ANOVA computed using the natural logarithm of the alpha data are closer to normal than the raw data, but they are still decidedly non-normal. The residuals for the raw beta data are not normally distributed, but the residuals for the ANOVA computed using the natural logarithm of the beta data are sufficiently normal to meet the requirements of ANOVA. It can be seen from both sets of figures that the residuals from the models computed using the natural logarithm of the data are more normally distributed than those from the models computed from the raw data. However, the residuals for the transformed alpha data are far from normally distributed. 

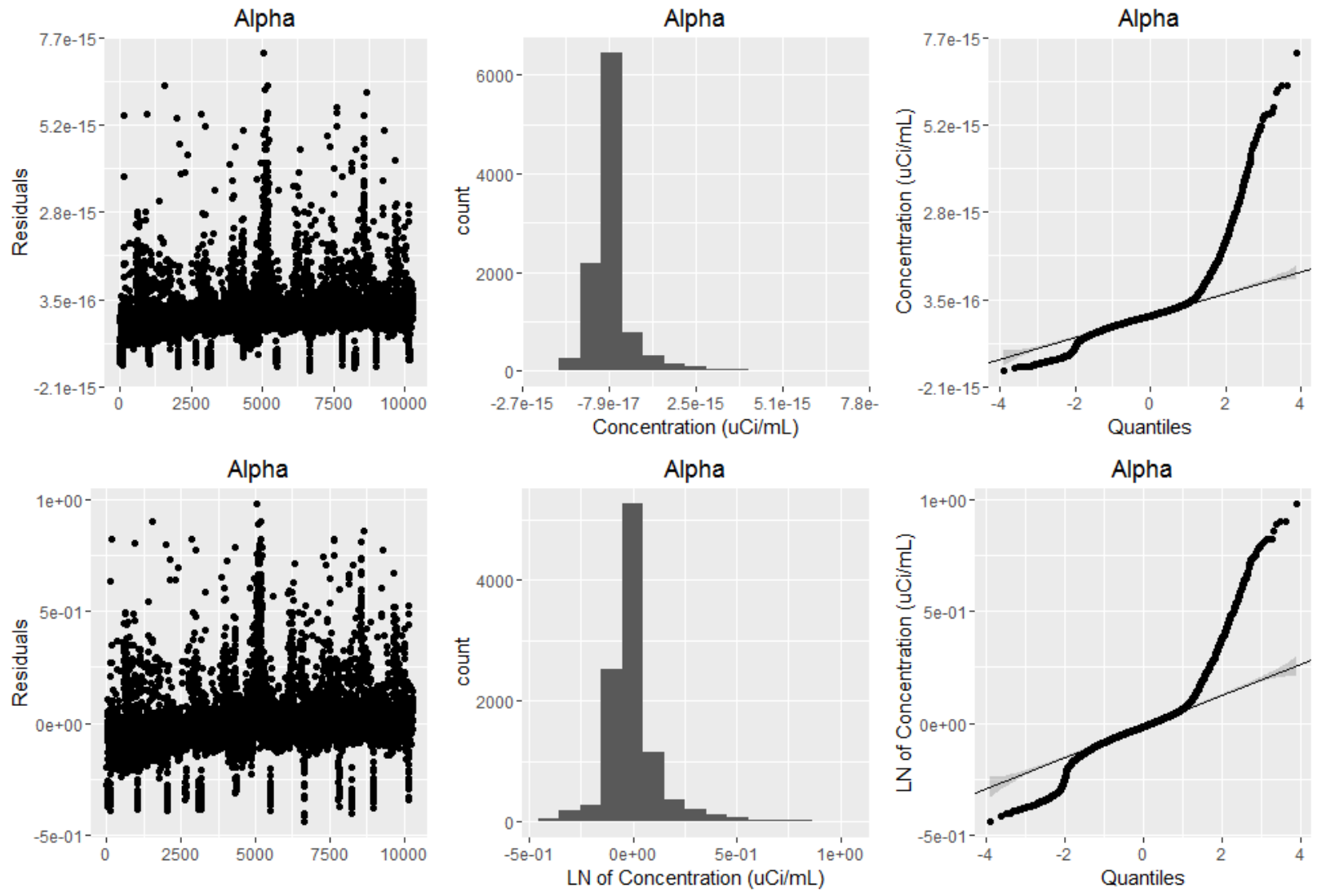

Figure 4. Residual plots, histograms, and normal-quantile plots of residuals from the ANOVA model generated using the raw alpha data and the natural logarithm of the alpha data. 

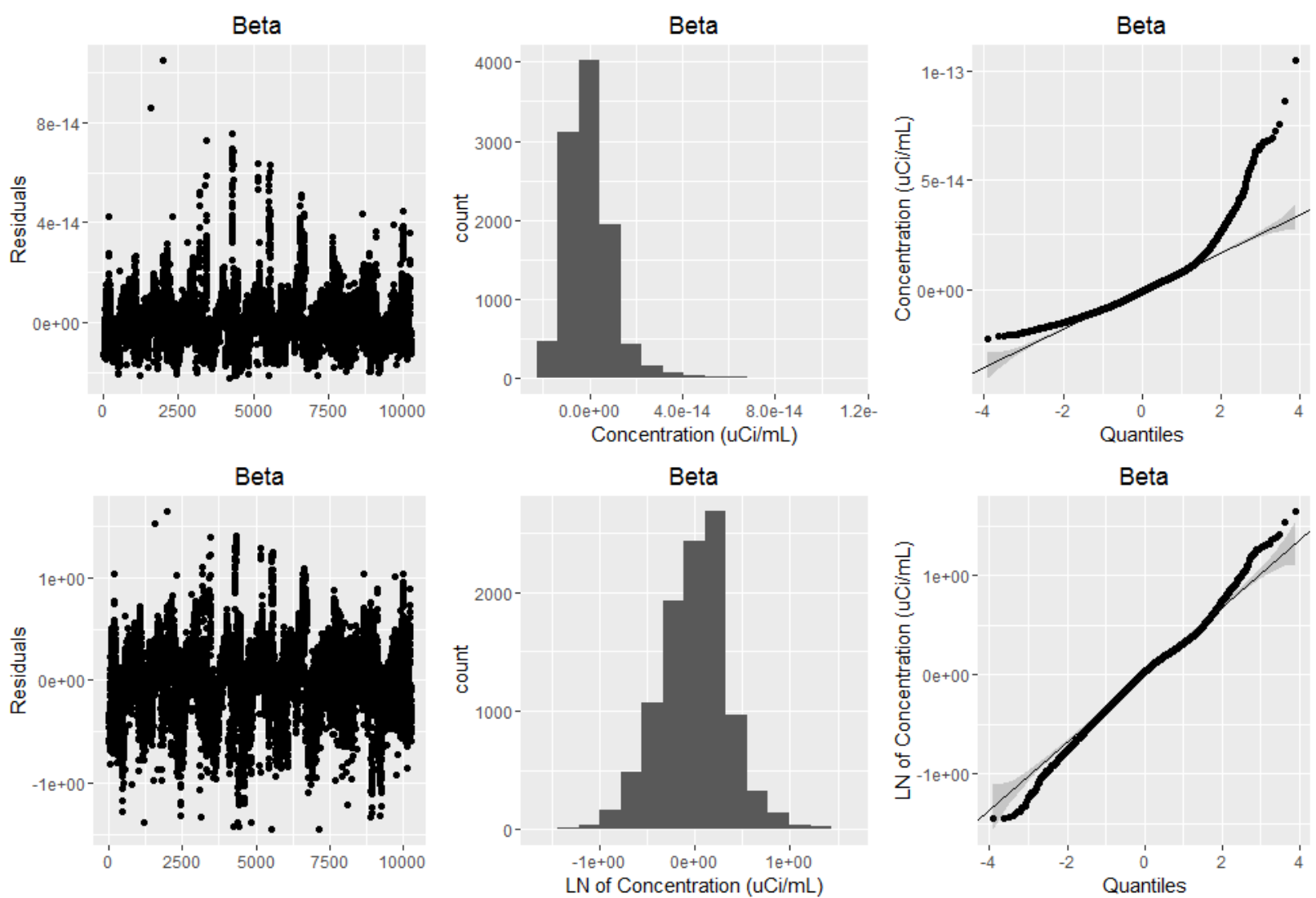

Figure 5. Residual plots, histograms, and normal-quantile plots of residuals from the ANOVA model generated using the raw beta data and the natural logarithm of the beta data.

The residuals for the gross alpha data indicate that ANOVA is not an appropriate statistical test for the data. The Kruskal-Wallis test is a similar statistical test that does not require that the residuals have a normal distribution. The Kruskal-Wallis test was used to determine if there is a difference between the median concentrations at each site. The p-value for the test was less than 0.0001 , which means that the median from at least one of the monitoring sites is different from at least one of the other sites. However, the Kruskal-Wallis test cannot identify the site, or sites, that are different. The Nemenyi test for multiple comparisons was done to determine which sites are different. This resulted in 780 comparison tests. Thirty-seven percent of the pair-wise comparison tests were statistically significant. This means that the median concentrations for several of the sites are statistically different than for other sites. Thus, the data are not stationary among sites, and gross alpha concentrations are expected to be higher at some sites than at other sites. Figure 6 shows a boxplot of the gross alpha concentrations measured at each site. They are ordered from highest median concentration to lowest median concentration. This graph can provide context when a measured alpha concentration exceeds the threshold at a specific site.

ANOVA was done on the natural logarithm of the gross beta data, and the results indicated that at least one of the sites differed from another site (p-value < 0.0001). Multiple means comparison testing using Tukey's honest significant difference was used to determine which of the sites differed from each other. This resulted in 780 comparisons for gross beta data, and $3.7 \%$ of the pair-wise comparison tests show a difference. This indicates that some of the sites are different than others. Figure 7 shows a boxplot of the observed gross beta concentrations at each site sorted according to median concentration. This graph can be used for context to determine which sites may consistently have higher concentrations than other sites. 


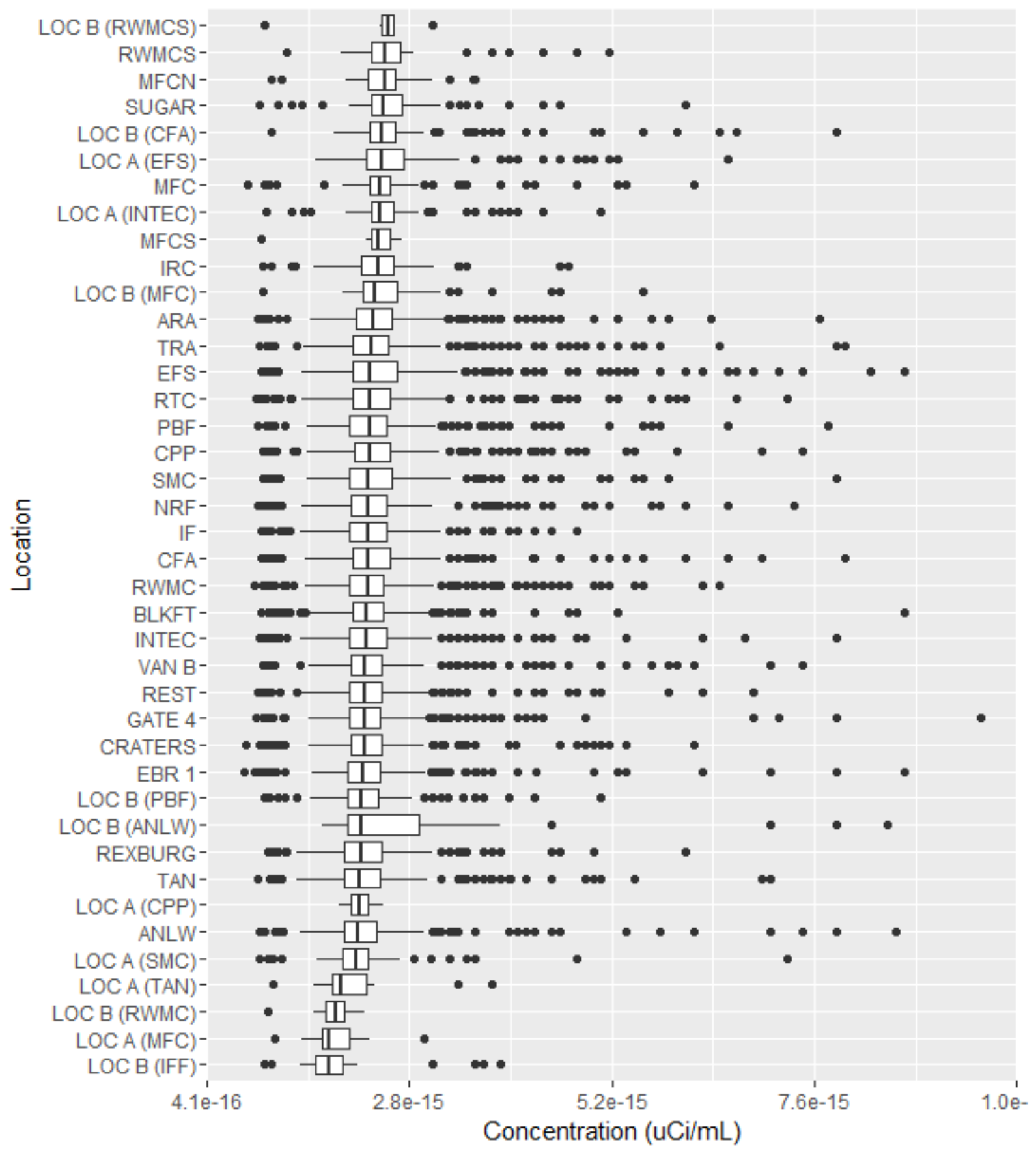

Figure 6. Boxplot showing the concentrations of alpha radiation in each monitor location. 


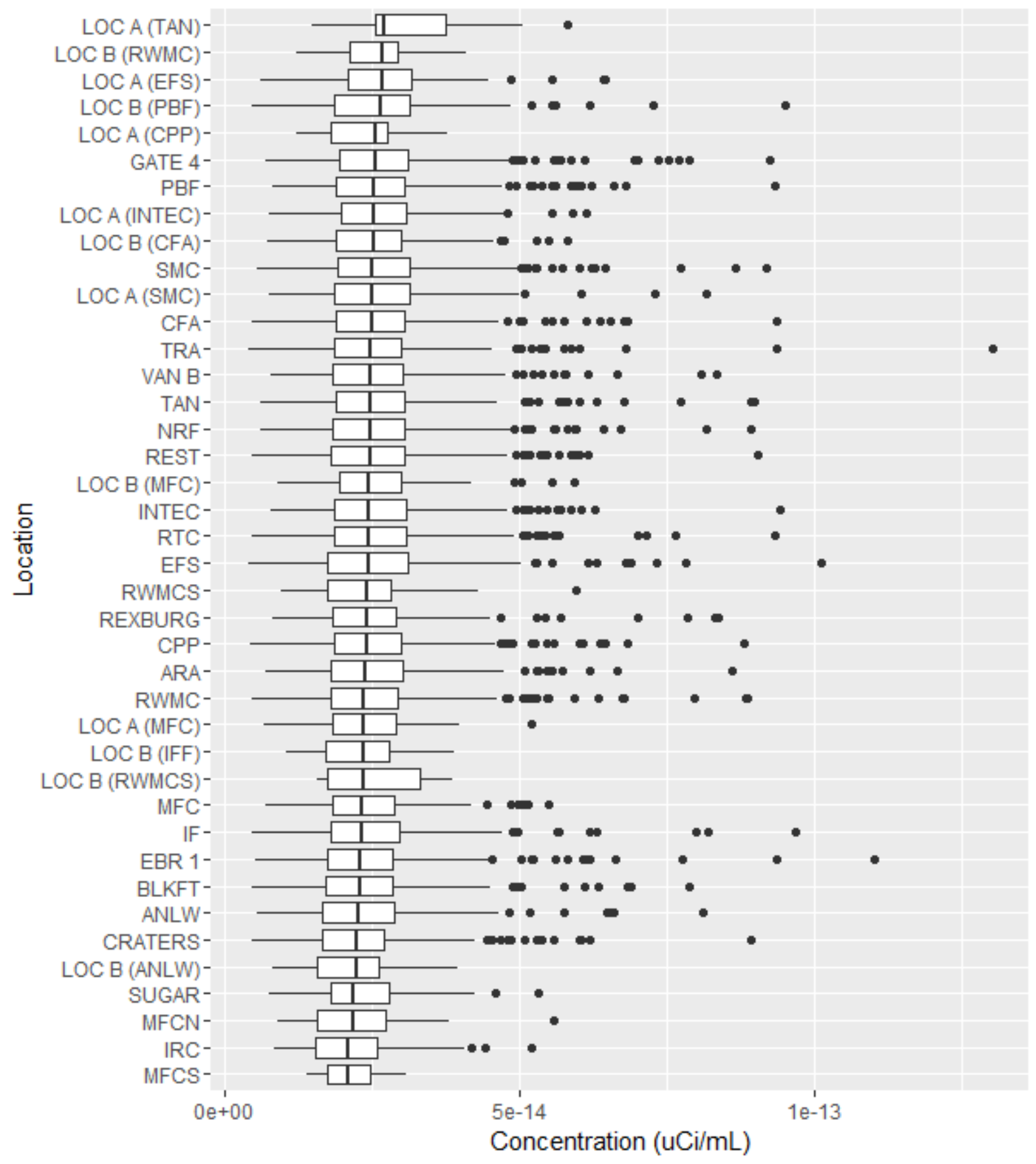

Figure 7. Boxplot showing the concentrations of beta radiation in each monitor location. 


\subsection{Summary Statistics}

Summary statistics and statistical plots are presented in this section. Plots include a histogram, normal-quantile plot, and boxplot. The histogram shows the overall shape, or distribution, of the data. It can identify outliers and skewness in the data. The normal-quantile plot illustrates whether the data follow a normal distribution. If the points in the graph follow a straight line then the data are considered normally distributed. Deviations from the line indicate that the data are not normally distributed. The boxplot graphs the minimum, first quartile, median, third quartile, and maximum observed values. It also shows potential outliers in the data with points above or below the lines. However, if the data are skewed, points in the tail will be shown as outliers even if they are not actual outliers. Figure 8 shows the plots for the gross alpha and gross beta concentrations. The graphs show that the neither dataset is normally distributed. They are both right-skewed. The data do not appear to have any outliers after the removal of the one cited in Section 2.1.
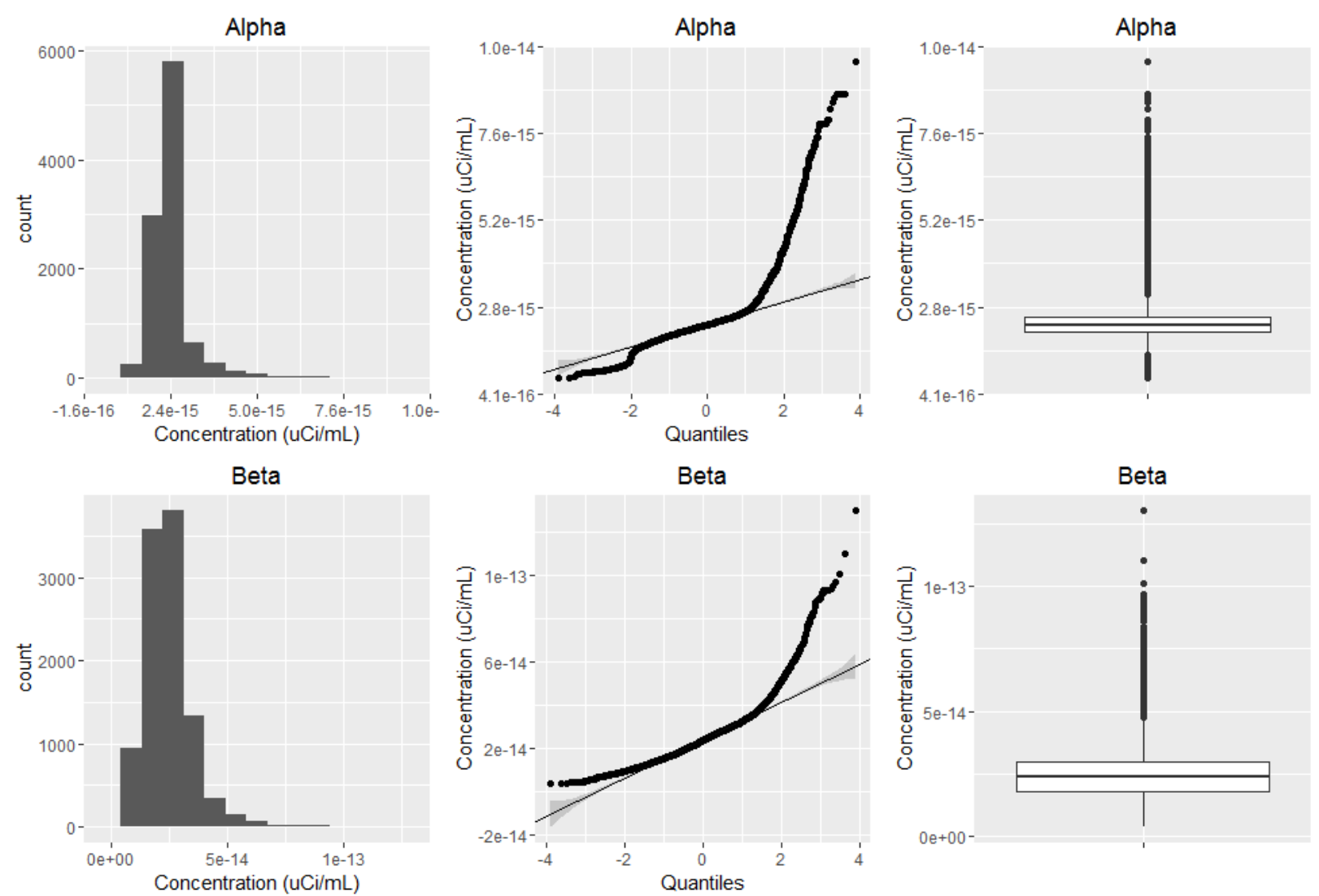

Figure 8. Histograms, normal-quantile plots, and boxplots for gross alpha and gross beta concentrations.

Summary statistics include the mean, standard deviation, and the five-number summary. The fivenumber summary is the minimum, first quartile, median, third quartile, and maximum concentration for the data set. Tables 1 and 2 show the summary statistics for the gross alpha concentrations, and Tables 3 and 4 show the summary statistics for the gross beta concentrations. Because the data are not stationary, the summary statistics are presented for each site and also for all of the sites combined. Note that the summary statistics are computed without the outliers identified in Section 2.1. 
Table 1. Summary statistics for gross alpha concentrations.

\begin{tabular}{|c|c|c|c|c|}
\hline Location & $\begin{array}{c}\text { Number of } \\
\text { Observations }\end{array}$ & $\begin{array}{l}\text { Number of } \\
\text { Detections }\end{array}$ & $\begin{array}{c}\text { Mean } \\
(\mu \mathrm{Ci} / \mathrm{mL})\end{array}$ & $\begin{array}{l}\text { Standard Deviation } \\
\qquad(\mu \mathrm{Ci} / \mathrm{mL})\end{array}$ \\
\hline All Sites & 10286 & 967 & $1.25 \mathrm{E}-15$ & 8.83E-16 \\
\hline ANLW & 262 & 22 & $2.40 \mathrm{E}-15$ & $9.32 \mathrm{E}-16$ \\
\hline ARA & 340 & 24 & $2.51 \mathrm{E}-15$ & 7.26E-16 \\
\hline BLKFT & 451 & 34 & $2.36 \mathrm{E}-15$ & $5.47 \mathrm{E}-16$ \\
\hline CFA & 451 & 47 & $2.45 \mathrm{E}-15$ & $7.11 \mathrm{E}-16$ \\
\hline СРP & 451 & 45 & $2.46 \mathrm{E}-15$ & $6.65 \mathrm{E}-16$ \\
\hline CRATERS & 446 & 18 & $2.34 \mathrm{E}-15$ & $5.62 \mathrm{E}-16$ \\
\hline EBR 1 & 450 & 30 & 2.37E-15 & 6.97E-16 \\
\hline EFS & 440 & 49 & 2.59E-15 & $9.60 \mathrm{E}-16$ \\
\hline GATE 4 & 450 & 42 & 2.38E-15 & 7.18E-16 \\
\hline IF & 453 & 42 & 2.37E-15 & $4.75 \mathrm{E}-16$ \\
\hline INTEC & 453 & 53 & $2.42 \mathrm{E}-15$ & $6.74 \mathrm{E}-16$ \\
\hline IRC & 159 & 9 & 2.47E-15 & $4.30 \mathrm{E}-16$ \\
\hline LOC A (CPP) & 7 & 1 & $2.23 \mathrm{E}-15$ & $1.83 \mathrm{E}-16$ \\
\hline LOC A (EFS) & 99 & 12 & $2.76 \mathrm{E}-15$ & 8.43E-16 \\
\hline LOC A (INTEC) & 153 & 15 & $2.55 \mathrm{E}-15$ & 4.79E-16 \\
\hline LOC A (MFC) & 38 & 3 & $1.95 \mathrm{E}-15$ & $3.42 \mathrm{E}-16$ \\
\hline LOC A (SMC) & 140 & 9 & $2.25 \mathrm{E}-15$ & 5.92E-16 \\
\hline LOC A (TAN) & 15 & 1 & $2.20 \mathrm{E}-15$ & $6.46 \mathrm{E}-16$ \\
\hline LOC B (ANLW) & 32 & 8 & 2.96E-15 & $1.71 \mathrm{E}-15$ \\
\hline LOC B (CFA) & 152 & 11 & $2.71 \mathrm{E}-15$ & 8.88E-16 \\
\hline LOC B (IFF) & 38 & 6 & 2.04E-15 & $6.61 \mathrm{E}-16$ \\
\hline LOC B (MFC) & 65 & 10 & 2.60E-15 & $6.74 \mathrm{E}-16$ \\
\hline LOC B (PBF) & 139 & 13 & $2.36 \mathrm{E}-15$ & $5.90 \mathrm{E}-16$ \\
\hline LOC B (RWMC) & 14 & 0 & $1.90 \mathrm{E}-15$ & $2.70 \mathrm{E}-16$ \\
\hline LOC B (RWMCS) & 6 & 0 & $2.40 \mathrm{E}-15$ & $6.77 \mathrm{E}-16$ \\
\hline MFC & 180 & 11 & $2.54 \mathrm{E}-15$ & $5.83 \mathrm{E}-16$ \\
\hline MFCN & 58 & 2 & $2.51 \mathrm{E}-15$ & $3.85 E-16$ \\
\hline MFCS & 7 & 0 & $2.31 \mathrm{E}-15$ & $5.68 \mathrm{E}-16$ \\
\hline NRF & 449 & 57 & 2.45E-15 & $6.82 \mathrm{E}-16$ \\
\hline PBF & 391 & 32 & $2.44 \mathrm{E}-15$ & $6.70 \mathrm{E}-16$ \\
\hline REST & 452 & 45 & 2.38E-15 & $6.29 \mathrm{E}-16$ \\
\hline REXBURG & 291 & 26 & 2.32E-15 & $5.47 \mathrm{E}-16$ \\
\hline RTC & 452 & 50 & $2.47 \mathrm{E}-15$ & $7.10 \mathrm{E}-16$ \\
\hline RWMC & 452 & 47 & $2.41 \mathrm{E}-15$ & $6.67 \mathrm{E}-16$ \\
\hline RWMCS & 55 & 4 & $2.66 \mathrm{E}-15$ & $6.55 \mathrm{E}-16$ \\
\hline SMC & 448 & 46 & $2.43 \mathrm{E}-15$ & $6.21 \mathrm{E}-16$ \\
\hline SUGAR & 158 & 9 & $2.60 \mathrm{E}-15$ & 5.13E-16 \\
\hline TAN & 292 & 32 & $2.40 \mathrm{E}-15$ & 7.44E-16 \\
\hline TRA & 448 & 56 & $2.50 \mathrm{E}-15$ & 7.76E-16 \\
\hline VAN B & 449 & 46 & 2.42E-15 & 7.48E-16 \\
\hline
\end{tabular}


Table 2. Five-number summary for gross alpha concentrations.

\begin{tabular}{|c|c|c|c|c|c|}
\hline Location & $\begin{array}{l}\text { Minimum } \\
(\mu \mathrm{Ci} / \mathrm{mL})\end{array}$ & $\begin{array}{l}\text { First Quartile } \\
(\mu \mathrm{Ci} / \mathrm{mL})\end{array}$ & $\begin{array}{c}\text { Median } \\
(\mu \mathrm{Ci} / \mathrm{mL})\end{array}$ & $\begin{array}{l}\text { Third Quartile } \\
\qquad(\mu \mathrm{Ci} / \mathrm{mL})\end{array}$ & $\begin{array}{c}\text { Maximum } \\
(\mu \mathrm{Ci} / \mathrm{mL})\end{array}$ \\
\hline All Sites & $8.50 \mathrm{E}-16$ & $2.13 \mathrm{E}-15$ & 2.33E-15 & $2.55 \mathrm{E}-15$ & $9.60 \mathrm{E}-15$ \\
\hline ANLW & $1.03 \mathrm{E}-15$ & $2.05 \mathrm{E}-15$ & $2.21 \mathrm{E}-15$ & $2.43 \mathrm{E}-15$ & 8.60E-15 \\
\hline ARA & $1.01 \mathrm{E}-15$ & $2.18 \mathrm{E}-15$ & $2.39 \mathrm{E}-15$ & 2.61E-15 & $7.70 \mathrm{E}-15$ \\
\hline BLKFT & $1.05 \mathrm{E}-15$ & $2.14 \mathrm{E}-15$ & 2.31E-15 & $2.51 \mathrm{E}-15$ & $8.70 \mathrm{E}-15$ \\
\hline CFA & $1.06 \mathrm{E}-15$ & $2.14 \mathrm{E}-15$ & 2.33E-15 & $2.58 \mathrm{E}-15$ & $8.00 \mathrm{E}-15$ \\
\hline СРP & $1.07 \mathrm{E}-15$ & $2.16 \mathrm{E}-15$ & 2.34E-15 & $2.58 \mathrm{E}-15$ & $7.50 \mathrm{E}-15$ \\
\hline CRATERS & 8.70E-16 & $2.12 \mathrm{E}-15$ & $2.28 \mathrm{E}-15$ & $2.48 \mathrm{E}-15$ & $6.20 \mathrm{E}-15$ \\
\hline EBR 1 & $8.50 \mathrm{E}-16$ & 2.09E-15 & $2.26 \mathrm{E}-15$ & $2.46 \mathrm{E}-15$ & $8.70 \mathrm{E}-15$ \\
\hline EFS & $1.05 \mathrm{E}-15$ & $2.14 \mathrm{E}-15$ & $2.35 \mathrm{E}-15$ & $2.66 \mathrm{E}-15$ & 8.70E-15 \\
\hline GATE 4 & $1.00 \mathrm{E}-15$ & $2.10 \mathrm{E}-15$ & $2.28 \mathrm{E}-15$ & $2.47 \mathrm{E}-15$ & $9.60 \mathrm{E}-15$ \\
\hline IF & $1.05 \mathrm{E}-15$ & $2.11 \mathrm{E}-15$ & 2.33E-15 & $2.55 \mathrm{E}-15$ & $4.80 \mathrm{E}-15$ \\
\hline INTEC & $1.03 \mathrm{E}-15$ & $2.11 \mathrm{E}-15$ & 2.30E-15 & $2.54 \mathrm{E}-15$ & $7.90 \mathrm{E}-15$ \\
\hline IRC & $1.08 \mathrm{E}-15$ & $2.24 \mathrm{E}-15$ & $2.44 \mathrm{E}-15$ & 2.63E-15 & $4.70 \mathrm{E}-15$ \\
\hline LOC A (CPP) & $1.99 \mathrm{E}-15$ & $2.12 \mathrm{E}-15$ & 2.23E-15 & 2.33E-15 & $2.51 \mathrm{E}-15$ \\
\hline LOC A (EFS) & $1.71 \mathrm{E}-15$ & 2.31E-15 & $2.48 \mathrm{E}-15$ & $2.76 \mathrm{E}-15$ & $6.60 \mathrm{E}-15$ \\
\hline LOC A (INTEC) & $1.12 \mathrm{E}-15$ & $2.36 \mathrm{E}-15$ & $2.46 \mathrm{E}-15$ & 2.62E-15 & $5.10 \mathrm{E}-15$ \\
\hline LOC A (MFC) & $1.22 \mathrm{E}-15$ & $1.79 \mathrm{E}-15$ & $1.86 \mathrm{E}-15$ & $2.11 \mathrm{E}-15$ & $3.00 \mathrm{E}-15$ \\
\hline LOC A (SMC) & 1.03E-15 & 2.03E-15 & 2.18E-15 & 2.33E-15 & 7.30E-15 \\
\hline LOC A (TAN) & $1.20 \mathrm{E}-15$ & $1.90 \mathrm{E}-15$ & $2.01 \mathrm{E}-15$ & 2.30E-15 & 3.80E-15 \\
\hline LOC B (ANLW) & $1.78 \mathrm{E}-15$ & $2.08 \mathrm{E}-15$ & $2.25 \mathrm{E}-15$ & $2.94 \mathrm{E}-15$ & $8.50 \mathrm{E}-15$ \\
\hline LOC B (CFA) & $1.17 \mathrm{E}-15$ & 2.34E-15 & $2.49 \mathrm{E}-15$ & $2.64 \mathrm{E}-15$ & $7.90 \mathrm{E}-15$ \\
\hline LOC B (IFF) & $1.09 \mathrm{E}-15$ & $1.71 \mathrm{E}-15$ & $1.86 \mathrm{E}-15$ & $2.02 \mathrm{E}-15$ & $3.90 \mathrm{E}-15$ \\
\hline LOC B (MFC) & $1.08 \mathrm{E}-15$ & 2.27E-15 & $2.41 \mathrm{E}-15$ & 2.67E-15 & $5.60 \mathrm{E}-15$ \\
\hline LOC B (PBF) & $1.09 \mathrm{E}-15$ & $2.08 \mathrm{E}-15$ & $2.25 \mathrm{E}-15$ & $2.44 \mathrm{E}-15$ & $5.10 \mathrm{E}-15$ \\
\hline LOC B (RWMC) & $1.13 \mathrm{E}-15$ & $1.82 \mathrm{E}-15$ & $1.94 \mathrm{E}-15$ & $2.05 \mathrm{E}-15$ & $2.28 \mathrm{E}-15$ \\
\hline LOC B (RWMCS) & $1.10 \mathrm{E}-15$ & $2.49 \mathrm{E}-15$ & $2.56 \mathrm{E}-15$ & $2.62 \mathrm{E}-15$ & 3.10E-15 \\
\hline MFC & 8.90E-16 & $2.34 \mathrm{E}-15$ & $2.47 \mathrm{E}-15$ & $2.58 \mathrm{E}-15$ & $6.20 \mathrm{E}-15$ \\
\hline MFCN & $1.18 \mathrm{E}-15$ & 2.33E-15 & $2.52 \mathrm{E}-15$ & $2.65 \mathrm{E}-15$ & $3.60 \mathrm{E}-15$ \\
\hline MFCS & $1.06 \mathrm{E}-15$ & $2.38 \mathrm{E}-15$ & $2.45 \mathrm{E}-15$ & $2.59 \mathrm{E}-15$ & 2.73E-15 \\
\hline NRF & $1.01 \mathrm{E}-15$ & 2.13E-15 & 2.33E-15 & $2.55 \mathrm{E}-15$ & $7.40 \mathrm{E}-15$ \\
\hline PBF & $1.01 \mathrm{E}-15$ & $2.11 \mathrm{E}-15$ & $2.34 \mathrm{E}-15$ & $2.55 \mathrm{E}-15$ & $7.80 \mathrm{E}-15$ \\
\hline REST & $1.02 \mathrm{E}-15$ & 2.10E-15 & $2.28 \mathrm{E}-15$ & $2.49 \mathrm{E}-15$ & $6.90 \mathrm{E}-15$ \\
\hline REXBURG & $1.14 \mathrm{E}-15$ & $2.04 \mathrm{E}-15$ & $2.24 \mathrm{E}-15$ & $2.48 \mathrm{E}-15$ & $6.10 \mathrm{E}-15$ \\
\hline RTC & $1.00 \mathrm{E}-15$ & $2.14 \mathrm{E}-15$ & $2.34 \mathrm{E}-15$ & $2.59 \mathrm{E}-15$ & 7.30E-15 \\
\hline RWMC & $9.70 \mathrm{E}-16$ & $2.10 \mathrm{E}-15$ & 2.32E-15 & $2.51 \mathrm{E}-15$ & $6.50 \mathrm{E}-15$ \\
\hline RWMCS & $1.35 \mathrm{E}-15$ & 2.37E-15 & $2.52 \mathrm{E}-15$ & $2.70 \mathrm{E}-15$ & $5.20 \mathrm{E}-15$ \\
\hline SMC & $1.08 \mathrm{E}-15$ & 2.11E-15 & 2.33E-15 & 2.60E-15 & 7.90E-15 \\
\hline SUGAR & $1.04 \mathrm{E}-15$ & 2.37E-15 & $2.50 \mathrm{E}-15$ & $2.74 \mathrm{E}-15$ & 6.10E-15 \\
\hline TAN & $1.01 \mathrm{E}-15$ & $2.04 \mathrm{E}-15$ & $2.23 \mathrm{E}-15$ & $2.46 \mathrm{E}-15$ & 7.10E-15 \\
\hline TRA & $1.03 E-15$ & $2.14 \mathrm{E}-15$ & 2.36E-15 & $2.57 \mathrm{E}-15$ & 8.00E-15 \\
\hline VAN B & $1.07 \mathrm{E}-15$ & 2.12E-15 & $2.29 \mathrm{E}-15$ & $2.48 \mathrm{E}-15$ & $7.50 \mathrm{E}-15$ \\
\hline
\end{tabular}


Table 3. Summary statistics for gross beta concentrations.

\begin{tabular}{|c|c|c|c|c|}
\hline Location & $\begin{array}{c}\text { Number of } \\
\text { Observations }\end{array}$ & $\begin{array}{l}\text { Number of } \\
\text { Detections }\end{array}$ & $\begin{array}{c}\text { Mean } \\
(\mu \mathrm{Ci} / \mathrm{mL})\end{array}$ & $\begin{array}{l}\text { Standard Deviation } \\
\qquad(\mu \mathrm{Ci} / \mathrm{mL})\end{array}$ \\
\hline All Sites & 10285 & 10268 & $2.50 \mathrm{E}-14$ & $1.03 \mathrm{E}-14$ \\
\hline ANLW & 261 & 261 & $2.38 \mathrm{E}-14$ & $1.02 \mathrm{E}-14$ \\
\hline ARA & 340 & 340 & $2.48 \mathrm{E}-14$ & $1.03 \mathrm{E}-14$ \\
\hline BLKFT & 451 & 450 & $2.36 \mathrm{E}-14$ & 9.53E-15 \\
\hline CFA & 451 & 451 & $2.56 \mathrm{E}-14$ & $1.01 \mathrm{E}-14$ \\
\hline СРP & 451 & 449 & $2.51 \mathrm{E}-14$ & $9.84 \mathrm{E}-15$ \\
\hline CRATERS & 446 & 445 & 2.29E-14 & 9.30E-15 \\
\hline EBR 1 & 450 & 450 & $2.40 \mathrm{E}-14$ & $1.09 \mathrm{E}-14$ \\
\hline EFS & 440 & 436 & $2.53 \mathrm{E}-14$ & $1.15 \mathrm{E}-14$ \\
\hline GATE 4 & 450 & 450 & $2.66 \mathrm{E}-14$ & 1.13E-14 \\
\hline IF & 453 & 451 & 2.43E-14 & $1.01 \mathrm{E}-14$ \\
\hline INTEC & 453 & 452 & $2.56 \mathrm{E}-14$ & $1.00 \mathrm{E}-14$ \\
\hline IRC & 159 & 159 & $2.12 \mathrm{E}-14$ & 7.85E-15 \\
\hline LOC A (CPP) & 7 & 7 & 2.37E-14 & 8.62E-15 \\
\hline LOC A (EFS) & 99 & 99 & 2.69E-14 & $1.08 \mathrm{E}-14$ \\
\hline LOC A (INTEC) & 153 & 153 & $2.60 \mathrm{E}-14$ & $9.54 \mathrm{E}-15$ \\
\hline LOC A (MFC) & 38 & 38 & $2.42 \mathrm{E}-14$ & 8.70E-15 \\
\hline LOC A (SMC) & 140 & 140 & 2.61E-14 & $1.09 \mathrm{E}-14$ \\
\hline LOC A (TAN) & 15 & 15 & $3.17 \mathrm{E}-14$ & $1.21 \mathrm{E}-14$ \\
\hline LOC B (ANLW) & 32 & 32 & 2.17E-14 & 8.19E-15 \\
\hline LOC B (CFA) & 152 & 152 & $2.55 \mathrm{E}-14$ & $9.34 \mathrm{E}-15$ \\
\hline LOC B (IFF) & 38 & 38 & $2.26 \mathrm{E}-14$ & $7.25 \mathrm{E}-15$ \\
\hline LOC B (MFC) & 65 & 65 & 2.59E-14 & $9.77 \mathrm{E}-15$ \\
\hline LOC B (PBF) & 139 & 138 & $2.68 \mathrm{E}-14$ & $1.23 \mathrm{E}-14$ \\
\hline LOC B (RWMC) & 14 & 14 & 2.61E-14 & $8.16 \mathrm{E}-15$ \\
\hline LOC B (RWMCS) & 6 & 6 & $2.53 \mathrm{E}-14$ & $9.87 \mathrm{E}-15$ \\
\hline MFC & 180 & 180 & 2.42E-14 & 8.90E-15 \\
\hline MFCN & 58 & 58 & $2.21 \mathrm{E}-14$ & $8.16 \mathrm{E}-15$ \\
\hline MFCS & 7 & 7 & 2.13E-14 & 5.77E-15 \\
\hline $\mathrm{NRF}$ & 449 & 449 & $2.54 \mathrm{E}-14$ & $1.04 \mathrm{E}-14$ \\
\hline PBF & 391 & 391 & $2.58 \mathrm{E}-14$ & $1.07 \mathrm{E}-14$ \\
\hline REST & 452 & 451 & $2.50 \mathrm{E}-14$ & $9.75 \mathrm{E}-15$ \\
\hline REXBURG & 291 & 291 & $2.48 \mathrm{E}-14$ & $1.04 \mathrm{E}-14$ \\
\hline RTC & 452 & 452 & $2.54 \mathrm{E}-14$ & $1.05 \mathrm{E}-14$ \\
\hline RWMC & 452 & 451 & $2.49 \mathrm{E}-14$ & $1.08 \mathrm{E}-14$ \\
\hline RWMCS & 55 & 55 & $2.41 \mathrm{E}-14$ & 8.80E-15 \\
\hline SMC & 448 & 447 & 2.63E-14 & $1.10 \mathrm{E}-14$ \\
\hline SUGAR & 158 & 158 & 2.27E-14 & $7.78 \mathrm{E}-15$ \\
\hline TAN & 292 & 292 & 2.61E-14 & $1.14 \mathrm{E}-14$ \\
\hline TRA & 448 & 447 & $2.53 \mathrm{E}-14$ & $1.09 \mathrm{E}-14$ \\
\hline VAN B & 449 & 448 & $2.53 \mathrm{E}-14$ & $9.92 \mathrm{E}-15$ \\
\hline
\end{tabular}


Table 4. Five-number summary for gross beta concentrations.

\begin{tabular}{|c|c|c|c|c|c|}
\hline Location & $\begin{array}{l}\text { Minimum } \\
(\mu \mathrm{Ci} / \mathrm{mL})\end{array}$ & $\begin{array}{l}\text { First Quartile } \\
\qquad(\mu \mathrm{Ci} / \mathrm{mL})\end{array}$ & $\begin{array}{c}\text { Median } \\
(\mu \mathrm{Ci} / \mathrm{mL})\end{array}$ & $\begin{array}{l}\text { Third Quartile } \\
\qquad(\mu \mathrm{Ci} / \mathrm{mL})\end{array}$ & $\begin{array}{l}\text { Maximum } \\
(\mu \mathrm{Ci} / \mathrm{mL})\end{array}$ \\
\hline All Sites & 3.89E-15 & $1.80 \mathrm{E}-14$ & $2.40 \mathrm{E}-14$ & $2.98 \mathrm{E}-14$ & $1.30 \mathrm{E}-13$ \\
\hline ANLW & 5.30E-15 & $1.64 \mathrm{E}-14$ & $2.26 \mathrm{E}-14$ & $2.88 \mathrm{E}-14$ & $8.11 \mathrm{E}-14$ \\
\hline ARA & $6.90 \mathrm{E}-15$ & $1.79 \mathrm{E}-14$ & 2.37E-14 & $3.02 \mathrm{E}-14$ & 8.60E-14 \\
\hline BLKFT & $4.40 \mathrm{E}-15$ & $1.70 \mathrm{E}-14$ & $2.28 \mathrm{E}-14$ & $2.85 \mathrm{E}-14$ & 7.86E-14 \\
\hline CFA & $4.50 \mathrm{E}-15$ & $1.89 \mathrm{E}-14$ & $2.48 \mathrm{E}-14$ & $3.04 \mathrm{E}-14$ & $9.34 \mathrm{E}-14$ \\
\hline СРP & $4.10 \mathrm{E}-15$ & $1.86 \mathrm{E}-14$ & 2.39E-14 & 2.99E-14 & $8.80 \mathrm{E}-14$ \\
\hline CRATERS & $4.40 \mathrm{E}-15$ & $1.65 \mathrm{E}-14$ & $2.24 \mathrm{E}-14$ & $2.70 \mathrm{E}-14$ & 8.90E-14 \\
\hline EBR 1 & $5.00 \mathrm{E}-15$ & $1.72 \mathrm{E}-14$ & $2.28 \mathrm{E}-14$ & $2.84 \mathrm{E}-14$ & $1.10 \mathrm{E}-13$ \\
\hline EFS & 3.89E-15 & $1.73 \mathrm{E}-14$ & $2.42 \mathrm{E}-14$ & $3.11 \mathrm{E}-14$ & $1.01 \mathrm{E}-13$ \\
\hline GATE 4 & $6.90 \mathrm{E}-15$ & $1.94 \mathrm{E}-14$ & $2.54 \mathrm{E}-14$ & $3.10 \mathrm{E}-14$ & $9.22 \mathrm{E}-14$ \\
\hline IF & $4.46 \mathrm{E}-15$ & $1.78 \mathrm{E}-14$ & $2.30 \mathrm{E}-14$ & 2.95E-14 & $9.68 \mathrm{E}-14$ \\
\hline INTEC & $7.70 \mathrm{E}-15$ & $1.85 \mathrm{E}-14$ & $2.42 \mathrm{E}-14$ & $3.06 \mathrm{E}-14$ & $9.42 \mathrm{E}-14$ \\
\hline IRC & 8.30E-15 & $1.52 \mathrm{E}-14$ & 2.09E-14 & $2.57 \mathrm{E}-14$ & 5.20E-14 \\
\hline LOC A (CPP) & $1.21 \mathrm{E}-14$ & $1.79 \mathrm{E}-14$ & $2.55 \mathrm{E}-14$ & $2.75 \mathrm{E}-14$ & 3.77E-14 \\
\hline LOC A (EFS) & $6.00 \mathrm{E}-15$ & $2.08 \mathrm{E}-14$ & $2.65 \mathrm{E}-14$ & 3.17E-14 & $6.45 \mathrm{E}-14$ \\
\hline LOC A (INTEC) & 7.30E-15 & $1.97 \mathrm{E}-14$ & $2.51 \mathrm{E}-14$ & $3.08 \mathrm{E}-14$ & 6.13E-14 \\
\hline LOC A (MFC) & $6.70 \mathrm{E}-15$ & $1.83 \mathrm{E}-14$ & 2.35E-14 & $2.91 \mathrm{E}-14$ & 5.19E-14 \\
\hline LOC A (SMC) & $7.40 \mathrm{E}-15$ & $1.86 \mathrm{E}-14$ & 2.49E-14 & $3.12 \mathrm{E}-14$ & 8.15E-14 \\
\hline LOC A (TAN) & $1.46 \mathrm{E}-14$ & $2.56 \mathrm{E}-14$ & $2.69 \mathrm{E}-14$ & $3.74 \mathrm{E}-14$ & $5.81 \mathrm{E}-14$ \\
\hline LOC B (ANLW) & $7.90 \mathrm{E}-15$ & $1.56 \mathrm{E}-14$ & 2.23E-14 & 2.62E-14 & 3.93E-14 \\
\hline LOC B (CFA) & $7.20 \mathrm{E}-15$ & $1.89 \mathrm{E}-14$ & $2.51 \mathrm{E}-14$ & 2.99E-14 & $5.79 \mathrm{E}-14$ \\
\hline LOC B (IFF) & $1.04 \mathrm{E}-14$ & $1.70 \mathrm{E}-14$ & $2.34 \mathrm{E}-14$ & $2.78 \mathrm{E}-14$ & 3.87E-14 \\
\hline LOC B (MFC) & 8.80E-15 & $1.94 \mathrm{E}-14$ & $2.42 \mathrm{E}-14$ & 2.98E-14 & $5.92 \mathrm{E}-14$ \\
\hline LOC B (PBF) & $4.40 \mathrm{E}-15$ & $1.86 \mathrm{E}-14$ & 2.63E-14 & $3.13 \mathrm{E}-14$ & $9.49 \mathrm{E}-14$ \\
\hline LOC B (RWMC) & $1.22 \mathrm{E}-14$ & 2.12E-14 & 2.67E-14 & 2.91E-14 & $4.08 \mathrm{E}-14$ \\
\hline LOC B (RWMCS) & $1.56 \mathrm{E}-14$ & $1.72 \mathrm{E}-14$ & 2.33E-14 & $3.29 \mathrm{E}-14$ & 3.84E-14 \\
\hline MFC & $6.90 \mathrm{E}-15$ & $1.81 \mathrm{E}-14$ & 2.32E-14 & $2.85 \mathrm{E}-14$ & 5.49E-14 \\
\hline MFCN & $8.80 \mathrm{E}-15$ & $1.57 \mathrm{E}-14$ & $2.16 \mathrm{E}-14$ & $2.71 \mathrm{E}-14$ & $5.58 \mathrm{E}-14$ \\
\hline MFCS & $1.38 \mathrm{E}-14$ & $1.73 \mathrm{E}-14$ & 2.07E-14 & 2.47E-14 & $3.06 \mathrm{E}-14$ \\
\hline $\mathrm{NRF}$ & $6.00 \mathrm{E}-15$ & $1.82 \mathrm{E}-14$ & $2.46 \mathrm{E}-14$ & $3.05 \mathrm{E}-14$ & 8.91E-14 \\
\hline PBF & $7.90 \mathrm{E}-15$ & $1.88 \mathrm{E}-14$ & $2.51 \mathrm{E}-14$ & $3.04 \mathrm{E}-14$ & $9.32 \mathrm{E}-14$ \\
\hline REST & $4.40 \mathrm{E}-15$ & $1.80 \mathrm{E}-14$ & $2.45 \mathrm{E}-14$ & $3.04 \mathrm{E}-14$ & $9.04 \mathrm{E}-14$ \\
\hline REXBURG & 8.00E-15 & $1.81 \mathrm{E}-14$ & $2.41 \mathrm{E}-14$ & $2.90 \mathrm{E}-14$ & 8.36E-14 \\
\hline RTC & $4.40 \mathrm{E}-15$ & $1.84 \mathrm{E}-14$ & $2.42 \mathrm{E}-14$ & 3.07E-14 & $9.32 \mathrm{E}-14$ \\
\hline RWMC & $4.60 \mathrm{E}-15$ & $1.78 \mathrm{E}-14$ & $2.35 \mathrm{E}-14$ & 2.92E-14 & 8.86E-14 \\
\hline RWMCS & $9.40 \mathrm{E}-15$ & $1.73 \mathrm{E}-14$ & $2.41 \mathrm{E}-14$ & $2.81 \mathrm{E}-14$ & $5.96 \mathrm{E}-14$ \\
\hline SMC & $5.40 \mathrm{E}-15$ & $1.92 \mathrm{E}-14$ & $2.50 \mathrm{E}-14$ & $3.14 \mathrm{E}-14$ & $9.18 \mathrm{E}-14$ \\
\hline SUGAR & $7.40 \mathrm{E}-15$ & $1.78 \mathrm{E}-14$ & $2.18 \mathrm{E}-14$ & $2.78 \mathrm{E}-14$ & $5.30 \mathrm{E}-14$ \\
\hline TAN & 6.10E-15 & $1.88 \mathrm{E}-14$ & $2.46 \mathrm{E}-14$ & $3.05 \mathrm{E}-14$ & 8.96E-14 \\
\hline TRA & $3.98 \mathrm{E}-15$ & $1.86 \mathrm{E}-14$ & $2.47 \mathrm{E}-14$ & $2.99 \mathrm{E}-14$ & $1.30 \mathrm{E}-13$ \\
\hline VAN B & 7.80E-15 & $1.81 \mathrm{E}-14$ & $2.46 \mathrm{E}-14$ & 3.02E-14 & 8.33E-14 \\
\hline
\end{tabular}




\section{DECISION LIMITS}

A single decision limit was computed for gross alpha and another for gross beta. A 99\%/95\% upper tolerance limit (UTL) was used to compute the decision limits. The UTL is a value such that 99\% of the population (all possible air measurements) is less than the UTL with 95\% confidence. Another common threshold is the 95\%/95\% UTL, which is the value such that 95\% of the population of air measurements will be less than the UTL with 95\% confidence. It was determined that the 99\%/95\% UTL is more appropriate for the air monitoring data because so many measurements are collected each year. With a $99 \% / 95 \%$ UTL it is expected that approximately $1 \%$ of the measurements will exceed the UTL if the concentration of gross alpha or gross beta is within the normal range. This means that if a concentration exceeds the UTL it does not necessarily indicate that the site is outside of the normal range. Rather, it indicates that the measurement should be closely examined to determine if it is unusually high. Table 5 shows the decision limits for gross alpha and gross beta. ProUCL was used to compute the UTLs (EPA 2016).

Table 5. Decision limits for gross alpha and gross beta air monitoring.

\begin{tabular}{l|c}
\multicolumn{1}{c|}{ Parameter } & Decision Limit $(\mu \mathrm{Ci} / \mathrm{mL})$ \\
\hline Gross Alpha & $5.60 \mathrm{E}-15$ \\
Gross Beta & $6.27 \mathrm{E}-14$ \\
\hline
\end{tabular}

Both the gross alpha and gross beta data show a strong seasonal trend. Concentrations of gross alpha tend to be higher in the summer, and concentrations of gross beta tend to be higher in the winter. This means that during these times it is likely that measured concentrations will exceed the UTL when the concentrations are within the normal range. Figures 9 and 10 show how the gross alpha and gross beta concentrations vary relative to the decisions limits during each month. These figures show which months commonly have exceedances.

There is also a lack of stationarity between sites for both the gross alpha and gross beta data. This means that exceedances are more likely at some sites than at others. For example, concentrations at EFS or CFA Location B are more likely to exceed the UTL when the sites are within their normal range than concentrations observed at Location B at RWMC. This information can be used to provide context to exceedances that will occur during monitoring. Figures 11 and 12 show boxplots of concentrations measured at each site, with the decision limit included in the graph. This allows the data user to identify sites where exceedances are more frequent. 


\section{Gross Alpha}

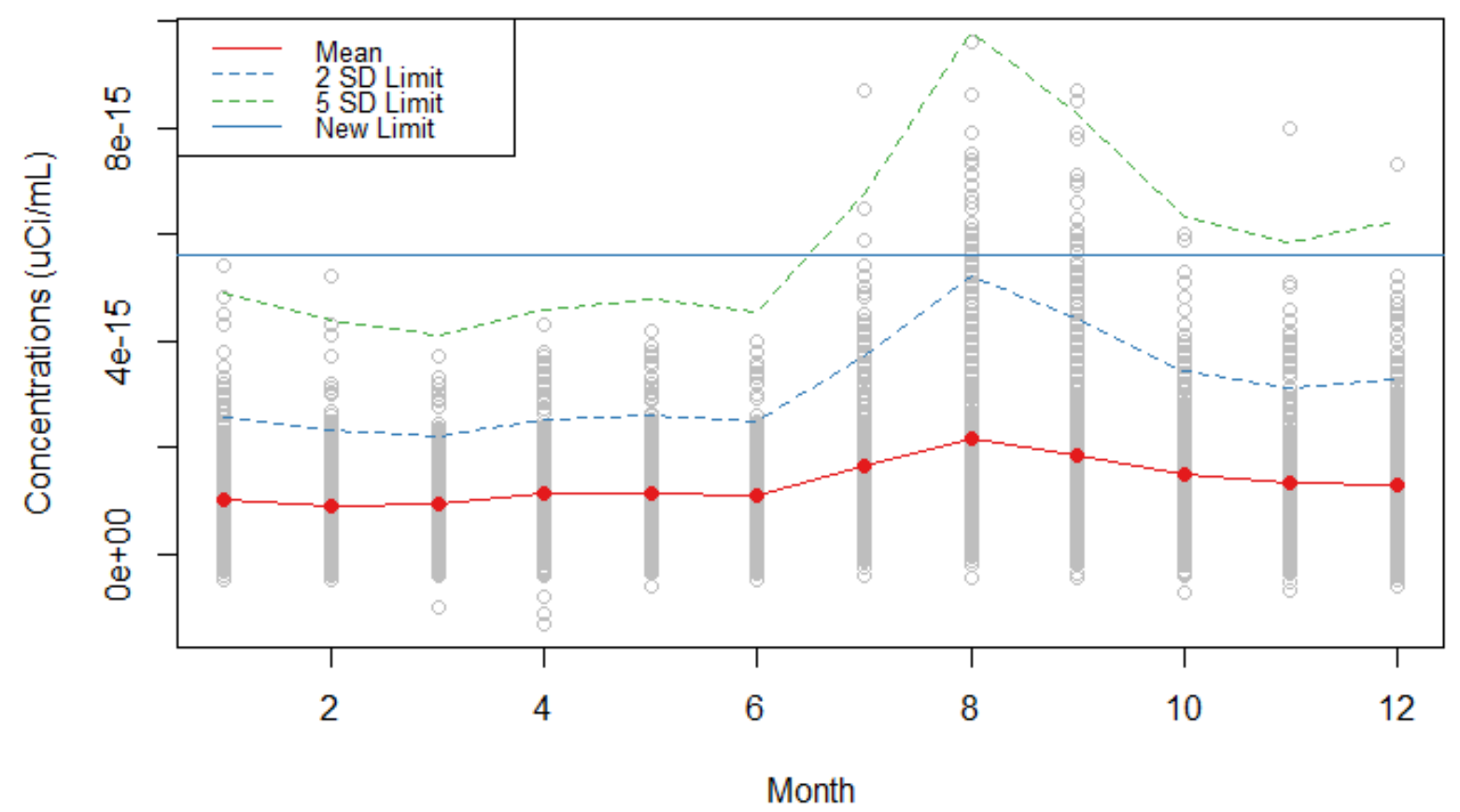

Figure 9. Gross alpha concentration by month. New decision limits are included for context.

\section{Gross Beta}

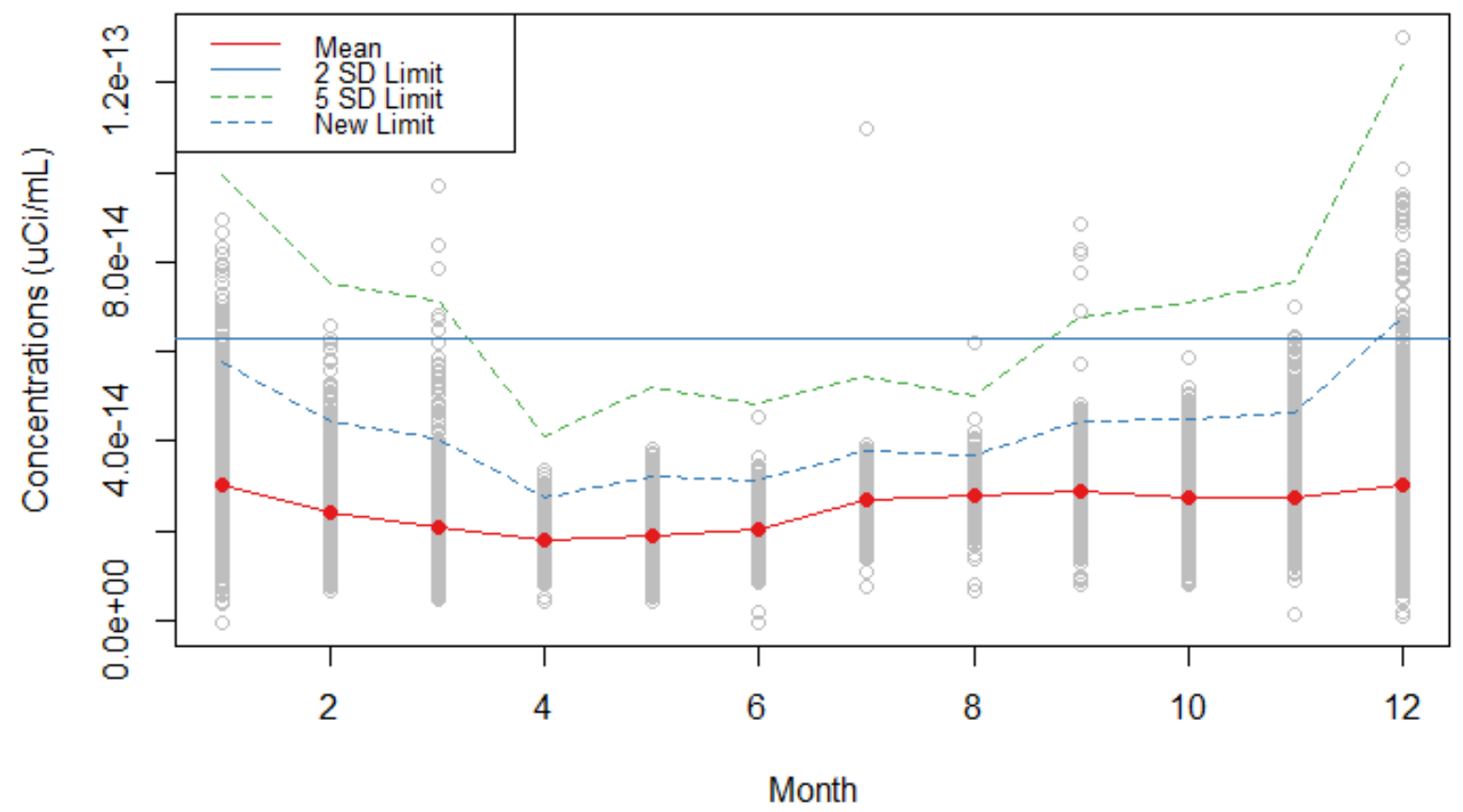

Figure 10. Gross beta concentration by month. New decision limits are included for context. 


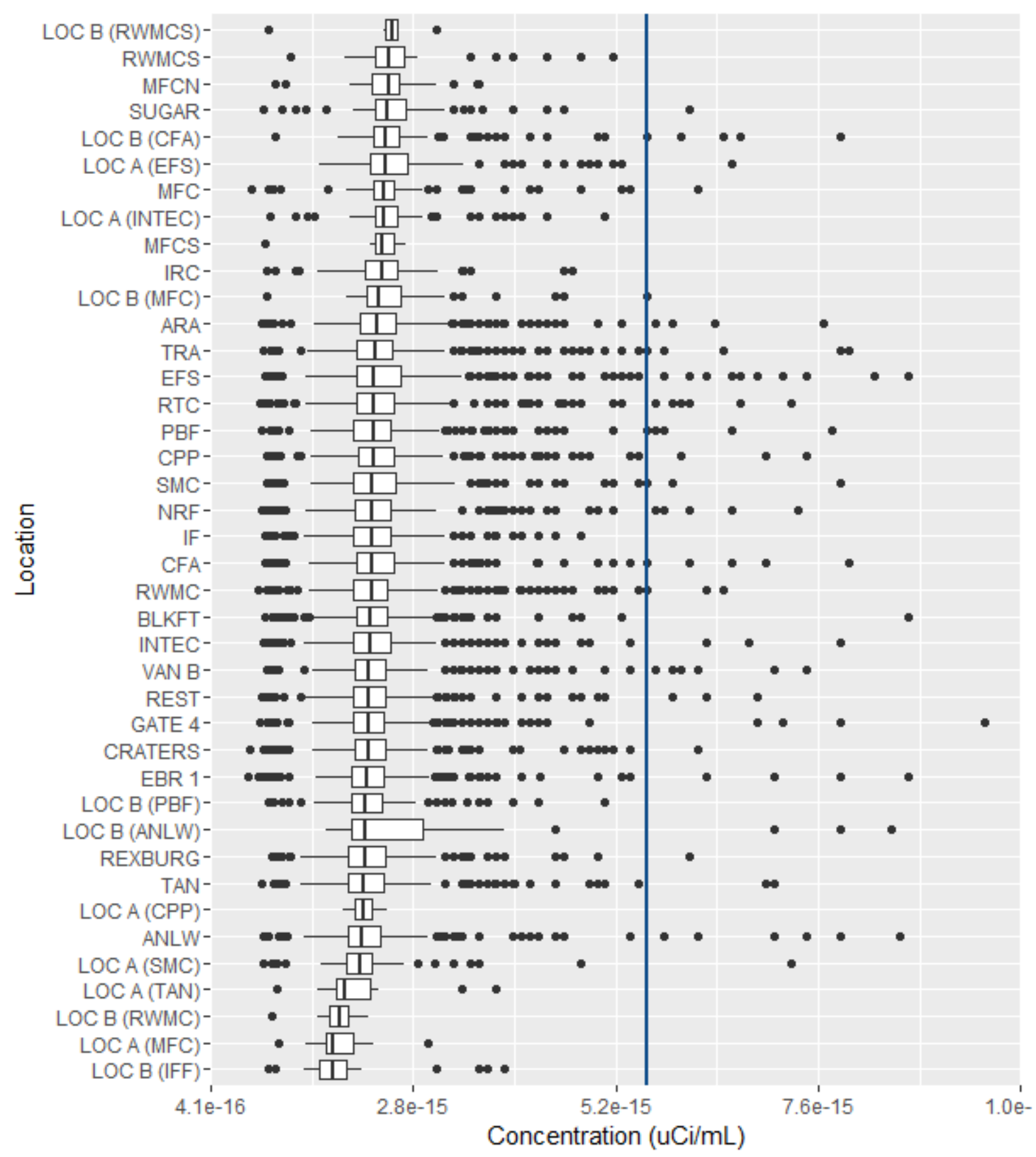

Figure 11. Alpha concentrations observed by location. The line on the graph is the decision limit, which is included for context. 


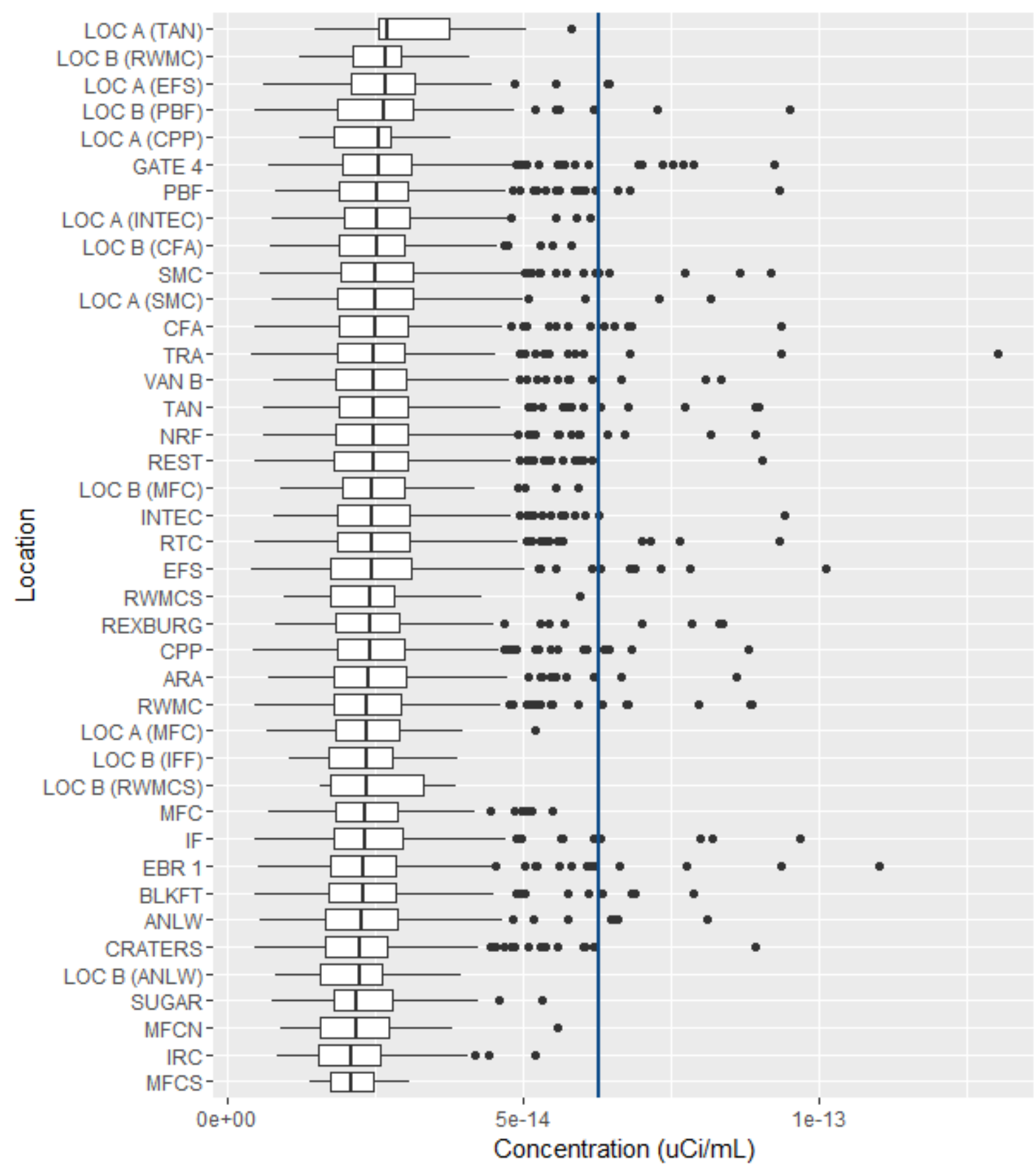

Figure 12. Beta concentrations observed by location. The line on the graph is the decision limit, which is included for context. 


\section{REFERENCES}

EPA, 2009, Statistical Analysis of Groundwater Monitoring Data at RCRA Facilities Unified Guidance, EPA 530/R-09-007, U.S. Environmental Protection Agency, March 2009.

EPA, 2016, ProUCL Version 5.1.002, http://www.epa.gov/osp/hstl/tsc/software.htm, Web page visited April 2017.

Gilbert, R. O., 1987, Statistical Methods for Environmental Pollution Monitoring, John Wiley \& Sons, Inc., 1987.

R Core Team, 2016, R: A Language and Environment for Statistical Computing, https://www.Rproject.org, R Foundation for Statistical Computing, Vienna, Austria.

Wickam, H., and R. Francois, 2015, Dplyr: A Grammar of Data Manipulation, https://CRAN.Rproject.org/package=dplyr, $\mathrm{R}$ package version 0.4.3.

Wickam, H., 2009, Ggplot2: Elegant Graphics for Data Analysis, Springer-Verlag, New York, 2009. 